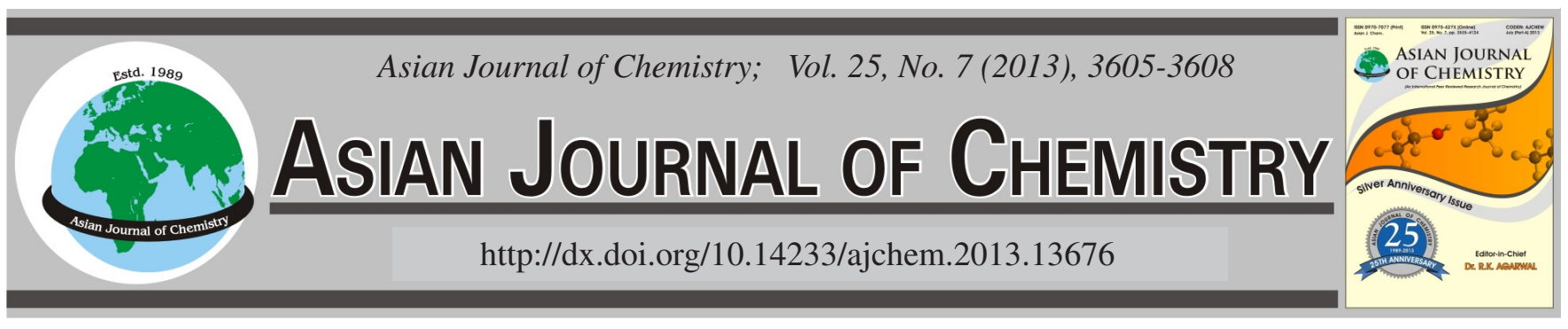

\title{
Evaluate the Effect of Some Chemicals (Phosphate, Nitrate and Silica) in Aquatic Systems of Epipelic Diatoms in Nisi Pond, Turkey
}

\author{
RIDVAN ERDAL SivACI
}

Department of Biology, Art and Science Faculty, Adiyaman University, Adiyaman, Turkey

Corresponding author: Fax: +90 416 2231774; Tel: +90 4162231775 /2073; E-mail: erdalsvac@gmail.com

\begin{abstract}
This work was described the relation between the epipelic diatom flora and physico-chemical of Nisi pond. Samples were collected monthly between December 2004 and June 2005 at random stations and $\mathrm{PO}_{4}-\mathrm{P}, \mathrm{PO}_{4}, \mathrm{P}_{2} \mathrm{O}_{5}, \mathrm{NO}_{3}-\mathrm{N}, \mathrm{NO}_{3}, \mathrm{Si}, \mathrm{SiO} 2, \mathrm{SO}, \mathrm{Cl}, \mathrm{pH}, \mathrm{O}_{2}$, temperature $\left({ }^{\circ} \mathrm{C}\right), \mathrm{Cl}-\mathrm{a}$ and Caretoneit were measured in water. Physico-chemical data of Nisi pond shown that concentrations of $\mathrm{P}_{2} \mathrm{O}_{5}$, $\mathrm{SiO}_{2}$ and $\mathrm{NO}_{3}-\mathrm{N}$ were negatively correlated with temperature. $\mathrm{PO}_{4}-\mathrm{P}$ and $\mathrm{PO}_{2}$ concentration of water were observed positively correlation with the density of epipelic diatoms. A total 34 taxa belonging to 16 genera were identified. In the study period, Cymatopleura solea (Brébisson) W. Smith, Cymbella affinis Kützing, Epithemia adnata (Kützing) Brébisson, Nitzschia amphibia Grunow. were the most dominant species.
\end{abstract}

Key Words: Diatom, Phosphate, Nitrate, Silica.

\section{INTRODUCTION}

Diatoms are perfect indicators for assessment of water and widely used in determining feature of lake ecosystems. Besides they are sensitive to lake water physico-chemical conditions such as $\mathrm{pH}$, nutrients and temperature. They usually account for the highest number of species among the primary producers in aquatic systems ${ }^{1}$. Seasonal succession of diatoms are conditioned by the join action of biotic and abiotic factors of environment in freshwater system ${ }^{2}$. Diatoms respond quickly to such changes because of their short life-period and differing tolerances to physical and chemical variables ${ }^{3,4}$. Hydrochemical changes may in turn affect the physiological response at diatoms and thus the species composition of the lake's biota, including that of ${ }^{5}$. Many studies have explored the relationship between diatom distribution and physicochemical characteristics of lake and diatom distribution have been carried weight ${ }^{6,7}$. Advances in methodology and statistical techniques have vastly improved our ability to infer relationship between lake water chemistry and epipelic diatoms flora. Diatoms are an important component of photosynthetic algal communities. The cell wall of diatoms is silicified to form a frustule, comprising two valves. In addition, diatoms have been recorded and classified for over 200 years in water systems ${ }^{8}$.

Description of the study site: Nisi pond located in east $2.5 \mathrm{~km}$ city of Sinop (42 $\left.1^{\prime} 19.89^{\prime \prime} \mathrm{N}\right)\left(35^{\circ} 11^{\prime} 15.51\right.$ "E) in Anatolia (Turkey). The pond has a surface area of maximum of $1.3 \mathrm{~km}^{2}$ and mean depths of $36.2 \mathrm{~m}$ and lies in a relatively nonfertile Nisi valley of the Kalkan stream, with a drainage area $11.4 \mathrm{~km}^{2}$.

This study focuses on the role of nutrients in determining the composition of epipelic diatom assemblages and investigated to influance of physico-chemical conditions on diatom flora of Nisi pond.

\section{EXPERIMENTAL}

Samples of diatom were taken during december 2004 and june 2005. It were collected by means of a glass pipe $11 \mathrm{~mm}$ in diameter and $1 \mathrm{~m}$ in length. The collected sediment samples were transferred into plastic bottles and taken to the laboratory for further examination. The samples were put into petri dishes and allowed to setle for 4-6 h. The supernatant was removed from the petri dishes by micropipetting and cover glasses were placed over the sediments. After $24 \mathrm{~h}$ the coverglasses were carefully taken and washed into beakers. Thereafter diatoms were prepared following standard techniques: carbonate dissolution by HCI followed by oxidation of organic matter using $\mathrm{H}_{2} \mathrm{O}_{2}{ }^{9}$. Two or three replicate slides were prepared for each sample. A total of 250-500 frustules per sample were identified and counted using phase contrast light microscopy $(1000 \mathrm{x})$. Species were identified according to Krammer and Lange-Bertalot ${ }^{10-13}$.

Descriptive statistics of 14 variables are summarized in Table-1. Dissolved oxygen concentration (DO), water tempe- 
TABLE-1

EPIPELIC DIATOM SPECIES OF NISI POND

\begin{tabular}{|c|c|}
\hline Divisio & Bacillariophyta \\
\hline Classis & Bacillariaophyceae \\
\hline Achnanthidium thermale & Rabenhorst \\
\hline Bacillaria paxillifera (O.F. Müller) & Hendey \\
\hline Cymatopleura elliptica (Brébisson) & W. Smith \\
\hline C. solea (Brébisson) & W. Smith \\
\hline Cymbella affinis & Kützing \\
\hline C. gibberula & Hustedt \\
\hline Reimeria sinuata (Gregory) & Kociolek \& Stoermer \\
\hline Encyonema silesiacum (Bleisch) & D.G. Mann \\
\hline Epithemia adnata (Kützing) & Brébisson \\
\hline E. argus (Ehrenberg) & Kützing \\
\hline E. sorex & Kützing \\
\hline Fragilaria brevistriata & Grunow \\
\hline Gomphonema olivaceum (Hornemann) & Brébisson \\
\hline G. parvulum (Kütz.) & Kütz. \\
\hline Hantzschia amphioxys (Ehrenberg) & Grunow \\
\hline Mastogloia smithii & Thwaites \\
\hline Navicula anglica & Ralfs \\
\hline N. cryptocephala & Kützing \\
\hline N. radiosa & Kützing \\
\hline N. reinhardtii & Grunow \\
\hline Neidium dubium (Ehr.) & Cleve \\
\hline Nitzschia amphibia & Grunow \\
\hline N. brevissima & Grunow \\
\hline N. commutata & Grunow \\
\hline N. ganderscheimensis & Krasske \\
\hline N. frustulum (Kütz.) & Grunow \\
\hline N. linearis (Agardh) & W. Smith \\
\hline N. palea (Kützing) & W. Smith \\
\hline N. pusilla & Grunow \\
\hline N. sigmoidea (Nitzsch) & W. Smith \\
\hline N. sublinearis & Hustedt \\
\hline Pinnularia viridis (Nitzsch) & Ehr. \\
\hline Sellaphora pupula (Kütz.) & Meres. \\
\hline Surirella angustata & Kützing \\
\hline S. minuta & Bréb. \\
\hline S. ovata & Kützing \\
\hline \multicolumn{2}{|c|}{ Classis Coscinodiscoph } \\
\hline
\end{tabular}

rature and $\mathrm{pH}$ were measured in the field. Water for chemical analyses was stored under cold dark conditions in acid-washed $1 \mathrm{~L}$ Pyrex bottles, following filtration through GF/C filters for ammonium, nitrate and soluble reactive phosphorus determinations. Unfiltered water was used for other variables. All analyses were completed within $18 \mathrm{~h}$ of sampling. Soluble reactive phosphorus (SRP), total soluble phosphorus (TSP), total phosphorus (TP), silicate $\left(\mathrm{SiO}_{3}\right)$, chlorine $\left(\mathrm{Cl}^{-}\right)$and ammonium $\left(\mathrm{NH}_{4}{ }^{+}\right)$and nitrate $\left(\mathrm{NO}_{3}{ }^{-}\right)$were determined according to Mackereth et al. ${ }^{14}$ to a precision of $\pm 4 \%$. Nitrate was determined by reduction to nitrite on spongycadmium and subsequent diazotization to a pink dye, determined spectrophotometrically, to aprecision of $\pm 3 \%$. For determination of chlorophyll-a concentration, water volumes of $500 \mathrm{mLwere}$ filtered immediately through $\mathrm{GF} / \mathrm{C}$ glass fiber filters after the addition of $0.2 \mathrm{~mL}$ saturated $\mathrm{MgCO}_{3}$. Filters were extracted in cold $90 \%$ acetone for 18-24 h. Following absorption measurements, the equations of Talling and Driver ${ }^{15}$ were used to determine chl- a concentrations corrected for phaeopigments.

Data analyses: Releationship among environmental variables $\left(\mathrm{PO}_{4}-\mathrm{P}, \mathrm{PO}_{4}, \mathrm{P}_{2} \mathrm{O}_{5}, \mathrm{NO}_{3}-\mathrm{N}, \mathrm{NO}_{3}, \mathrm{Si}, \mathrm{SiO}_{2}, \mathrm{SO}_{4}, \mathrm{Cl}, \mathrm{pH}\right.$, $\mathrm{O}_{2}$, temperature $\left({ }^{\circ} \mathrm{C}\right), \mathrm{Cl}-\mathrm{a}$ and caretoneid) were detected by scatter-plot of paired variables. Pearson correlation coefficients were calculated within and among the environmental variables and diatom species using the software package SPSS. The statistical significance was also calculated using this program.

\section{RESULTS AND DISCUSSION}

A total 37 taxa belonging to 18 genera were identified in Nisi pond (Table-1). Cymatopleura, Epithemia, Cymbella and Nitzschia were main genera found and Cymatopleura solea, Cymbella affinis, Epithemia adnata and Nitzschia amphibia, were the dominant taxa. Nitzschia palea, Cymatopleura elliptica and Pinnularia viridis, were found frequently and in large number. The epipelic diatoms in Nisi pond is diverse and periodically abundant. The seasonal variation in biomass regularly includes spring and a late summer maximum which showing consistency with the concentration change of Si and $\mathrm{SiO}_{2}$ (Fig. 1). The former is dominated such as Cymatopleura solea, while the summer maximum is often dominated by Nitzschia genus and sometimes Epithemia by slow-growing populations of the Neidium and Surirella. In autumn and winter, as Encyonema silesiacum and Nitzschia amphibia, along with Navicula species, are usually dominant.

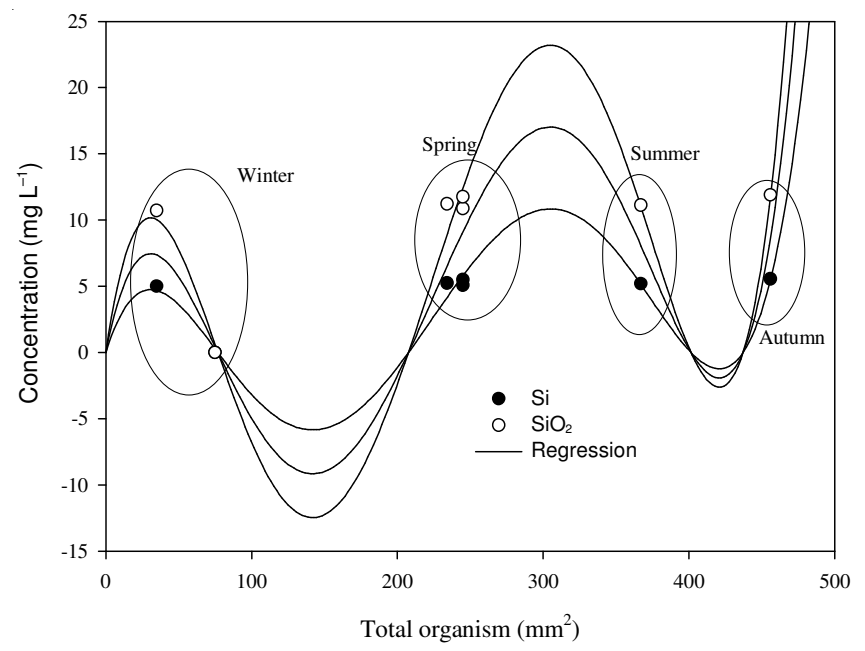

Fig. 1. Seasonal variation of the total organism to the effect of $\mathrm{Si}$ and $\mathrm{SiO}_{2}$

Numerous inorganic nutrients are necessary for diatom growts. Phosphate, nitrate and silica have vital importance in diatoms, which photosynthesise in the aquatic environment ${ }^{16}$. They are in the structure of chlorophyll and protein. Espeacially The concentration of phosphate has a great effect on algae growing in lakes ${ }^{17}$. As a results, the primer production in Lake are influenced ${ }^{18}$. Phosphorus in aquatic environments, multifaceted and complex chemical and biochemical balance is one of the key elements and the classification of lakes according to the level of nutrients has an important place. Lakes, ponds and streams can be categorized on the basis of their trophic status and consequences of this for diatoms growth. Oligotrophic and mesotrophic freshwater systems are generally clear, having a low concentration of plant life. Eutrophic freshwater are enriched with nutrients, resulting in elevated plant growth and often algal blooms. The trophic status classification developed by the Organization for Economic Co-operation and Development (OECD) ${ }^{19}$ based on total phosphorus (TP), 
chlorophyll a (Chl-a) and Secchi depth is given in Table-4. Chlorophyll data shows that Nisi pound has the characteristics of oligotrophic waters throught mesotrofic. This condition is also supported by the significant negative relationship between Chl-a and nutrient variables (Table-2). Epipelic communities take up a large amount of nutrients during their growth period. The chlorophyll-a concentrations in all seasons are generally moderate. Generally, the chlorophyll values in oligotrophic lakes have quite low chlorophyll concentration $\left(<7 \mathrm{mg} / \mathrm{m}^{3}\right)^{17}$. The highest chlorophyll-a value was seen in Spring and Autumn and from 19.14-9.1 $\mu \mathrm{g} / \mathrm{L}^{-1}$, respectively carotene in the same season, 23-26.6 $\mu \mathrm{g} / \mathrm{L}^{-1}$, calculated as. One of the main factor in affecting this fluctuation is the amount of orthophosphate. Looking at the curve in the concentration range Regresyonal 0.2 and 0.3 have occurred in the most narrow and high peak can be seen (Fig. 2) $(p=0.05)$.

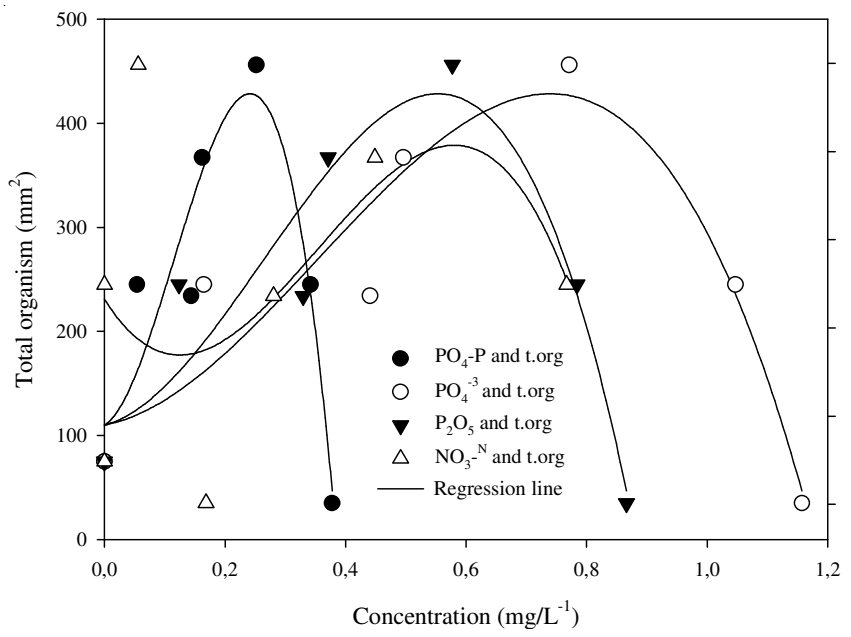

Fig. 2. Regresyonal relation to total organism of some chemical parameters in Nisi pond
Temperature has been shown to be an important regulator of chemical conditions in lakes ${ }^{20}$. Nisi nutrient data shown that concentrations of $\mathrm{P}_{2} \mathrm{O}_{5}, \mathrm{SiO}_{2}$ and $\mathrm{NO}_{3}-\mathrm{N}$ are negatively correlated with temperature (Table-2). Increasing temperatures accelerate growth rates of epipelic diatom, which consume nutrients. This process is also supported by the significant negative relationship between Chl-a and nutrient variables, which suggests that epipelic diatom communities take up a large amount of nutrients during their growth period. Temperature changes impact significantly on the rate of nutrient release and accumulation, which exhibit distinct seasonal cycles and further affect the biological characteristics of the pond. The average water temperature during the study varied between 5 \pm 0.5 and $28 \pm 1{ }^{\circ} \mathrm{C}$, the lowest value in winter, while the highest value was measured in summer month. The average $\mathrm{pH}$ is 7.1-8.5 ranged. The highest $\mathrm{pH}$ value was found in summer and autumn month while the lowest value was found in winter. The average value of dissolved oxygen with $8.7 \pm$ 0.1 from $11 \pm 0.5 \mathrm{mg} / \mathrm{L}^{-1}$ ranged. In autumn, the lowest value measured in winter was the highest value. The highest values of silicon $5.6 \mathrm{mg} / \mathrm{L}^{-1}$ value was observed in winter and the lowest amount was observed in autumn. Respectively, oxidized silicon in the winter $11.898 \mathrm{mg} / \mathrm{L}^{-1}$ are observed in the lowest value is $10.7 \mathrm{mg} / \mathrm{L}^{-1}$ months.

Physico-chemical data of Nisi pond shown that concentrations of $\mathrm{P}_{2} \mathrm{O}_{5}, \mathrm{SiO}_{2}$ and $\mathrm{NO}_{3}-\mathrm{N}$ were negatively correlated with temperature. $\mathrm{PO}_{4}-\mathrm{P}$ and $\mathrm{PO}_{2}$ concentration of water were observed positively correlation with the density of epipelic diatoms. Close correlations were found between physicochemical parameters and the growth of individual diatom species. Amount of total organism responded to climate variables (temperature) and nutrient variables ( $\mathrm{SRP}, \mathrm{SiO}_{2}$ and $\mathrm{NO}_{3}-\mathrm{N}$ ) at different significance levels. Nutrient variables $\mathrm{SRP}, \mathrm{NO}_{3}-\mathrm{N}$ and

\begin{tabular}{|c|c|c|c|c|c|c|c|c|}
\hline \multicolumn{9}{|c|}{$\begin{array}{l}\text { TABLE-2 } \\
\text { CORRELATION MATRIX OF ENVIRONMENTAL VARIABLES MEASURE } \\
\text { DATA OF NISI POND SIGNIFICANT VALUES ARE SHOWN IN* }(p<0.05) \text {. }\end{array}$} \\
\hline & $\mathrm{P}_{2} \mathrm{O}_{5}$ & $\mathrm{NO}_{3}-\mathrm{N}$ & $\mathrm{NO}_{3}$ & $\mathrm{Si}$ & $\mathrm{SiO}_{2}$ & Temperature $\left({ }^{\circ} \mathrm{C}\right)$ & $\mathrm{Cl}-\mathrm{a}$ & Carotene \\
\hline $\mathrm{P}_{2} \mathrm{O}_{5}$ & 1 & - & - & - & - & - & - & - \\
\hline $\mathrm{NO}_{3}-\mathrm{N}$ & $0.523 *$ & 1 & - & - & - & - & - & - \\
\hline $\mathrm{NO}_{3}$ & $0.678^{*}$ & -0.183 & 1 & - & - & - & - & - \\
\hline $\mathrm{Si}$ & $0.567 *$ & $0.345^{*}$ & $0.267 *$ & 1 & - & - & - & - \\
\hline $\mathrm{SiO}_{2}$ & $0.243^{*}$ & $0.245^{*}$ & 0.023 & $-0.651 *$ & 1 & - & - & - \\
\hline Temperature $\left({ }^{\circ} \mathrm{C}\right)$ & $-0.645^{*}$ & $-0.348^{*}$ & $0467 *$ & $-0.308^{*}$ & $-0.435^{*}$ & 1 & - & - \\
\hline $\mathrm{Cl}-\mathrm{a}$ & $-0.713 *$ & $-0.543 *$ & $-0.365^{*}$ & $-0.712 *$ & $-0.535^{*}$ & $0.346^{*}$ & 1 & - \\
\hline Carotene & $0.446 *$ & $0.649 *$ & -0.031 & -0.132 & -0.032 & 0.023 & $-0.325^{*}$ & 1 \\
\hline
\end{tabular}

TABLE-3

AVARAGE WATER CHEMISTRY MESURMENT OF NISI POND

\begin{tabular}{|c|c|c|c|c|c|c|c|c|c|c|c|c|c|c|}
\hline & $\begin{array}{c}\mathrm{PO}_{4^{-}} \\
\mathrm{P}\end{array}$ & $\mathrm{PO}_{4^{-}}{ }^{3}$ & $\mathrm{P}_{2} \mathrm{O}_{5}$ & $\begin{array}{c}\mathrm{NO}_{3}^{-} \\
\mathrm{N}\end{array}$ & $\mathrm{NO}_{3}$ & $\mathrm{Si}$ & $\mathrm{SiO}_{2}$ & $\mathrm{SO}_{4}$ & Chlorit & $\mathrm{pH}$ & $\mathrm{DO}_{2}$ & $\begin{array}{c}\text { Temp. } \\
\left({ }^{\circ} \mathrm{C}\right)\end{array}$ & $\mathrm{Cl}-\mathrm{a}$ & Carotene \\
\hline Mean & 0.190 & 0.582 & 0.436 & 0.246 & 1.088 & 4.514 & 9.658 & 255.2 & 114.274 & 7.920 & 8.884 & 13.214 & 10.104 & 16.514 \\
\hline Median & 0.162 & 0.496 & 0.371 & 0.168 & 0.745 & 5.200 & 11.124 & 268.0 & 90.900 & 7.950 & 8.710 & 13.000 & 5.280 & 16.800 \\
\hline Std. dev. & 0.141 & 0.433 & 0.324 & 0.282 & 1.248 & 2.001 & 4.281 & 56.198 & 52.180 & 0.565 & 1.834 & 10.713 & 8.146 & 9.261 \\
\hline Str. err. & 0.053 & 0.163 & 0.122 & 0.107 & 0.472 & 0.756 & 1.618 & 21.241 & 19.722 & 0.214 & 0.693 & 4.049 & 3.079 & 3.500 \\
\hline $95 \%$ conf & 0.131 & 0.400 & 0.299 & 0.261 & 1.154 & 1.850 & 3.959 & 51.976 & 48.260 & 0.523 & 1.696 & 9.908 & 7.534 & 8.565 \\
\hline $99 \%$ conf & 0.198 & 0.606 & 0.454 & 0.395 & 1.749 & 2.804 & 5.999 & 78.755 & 73.124 & 0.792 & 2.570 & 15.014 & 11.415 & 12.978 \\
\hline Total & 1.332 & 4.077 & 3.052 & 1.720 & 7.618 & 31.601 & 67.607 & 1787.0 & 799.920 & 55.440 & 62.190 & 92.500 & 70.730 & 115.6 \\
\hline Min & 0.000 & 0.000 & 0.000 & 0.000 & 0.000 & 0.000 & 0.000 & 175.0 & 72.720 & 7.180 & 6.350 & 1.000 & 1.540 & 4.000 \\
\hline Max & 0.378 & 1.157 & 0.866 & 0.767 & 3.395 & 5.561 & 11.898 & 309.0 & 218.160 & 8.580 & 11.620 & 28.300 & 19.140 & 26.800 \\
\hline Min. pos & 0.054 & 0.165 & 0.124 & 0.056 & 0.248 & 5.013 & 10.725 & 175.0 & 72.720 & 7.180 & 6.350 & 1.000 & 1.540 & 4.000 \\
\hline
\end{tabular}


TABLE-4

CLASSIFICATION OF FRESHWATER TROPHIC STATUS BY OECD (1982)

\begin{tabular}{lccccc}
\hline Category of trophic & Mean TP $\left(\mu \mathrm{g} \mathrm{L}^{-1}\right)$ & Mean Chl-a $\left(\mu \mathrm{g} \mathrm{L}^{-1}\right)$ & Max. chl-a $\left(\mu \mathrm{g} \mathrm{L}{ }^{-1}\right)$ & Mean Secchi depth $(\mathrm{m})$ & Min. Secchi depth $(\mathrm{m})$ \\
\hline Oligotrophic & $<10$ & $<2.5$ & $<8$ & $>6$ & $>3$ \\
Mesotrophic & $10-35$ & $2.5-8.0$ & $8-25$ & $6-3$ & $3.0-1.5$ \\
Eutrophic & $>35$ & $>8$ & $>25$ & $<3$ & $<1.5$ \\
\hline
\end{tabular}

$\mathrm{SiO}_{2}$, which negatively responded to changes in temperatures, imposed significant impacts on the growth of all species.

\section{REFERENCES}

1. J.R. Stevenson and Y. Pan, In eds.: E.F. Stoermer and J.P. Smol, Assessing Environmental Conditions in Rivers and Streams with Diatoms, Cambridge University Press, Cambridge, London, p. 40 (1999).

2. R.A. Danilov, Int. J. Alg., 4, 24 (2002).

3. R.W. Battarbee, D.F. Charles, S. Dixit and S.I. Renberg, In eds.: E.F Stoermer and J.P. Smol, Diatoms as Indicators of Surface Water Acidity, Cambridge University Press Ltd., Cambridge, London, p. 127 (1999).

4. A.F. Lotter, R. Pienitz and R. Schmidt, In eds.: E.F. Stoermer and J.P. Smol, Diatoms as Indicators of Environmental Change Near Arctic and Alpine Treline, Cambridge University Press Ltd., Cambridge, London, p. 226 (1999).

5. J.E. Saros and S.C. Fritz, Fresh Biol., 26, 95 (2002).

6. G.J. Chen, C. Dalton, M. Leira and D. Taylor, J. Paleo., 40, 163 (2008).

7. N. Salmaso, Fresh Biol., 55, 846 (2009).

8. B.P. Horton, R. Corbett, S.J. Culver, R.J. Edwards and C. Hillier, Estuarine Coast. Shelf Sci., 69, 381 (2006).

9. W. Batterbee, In ed.: B.E. Berglund, Diatom Analysis, Handbook of Holocene Palaeoecology, London, p. 570 (1986).

10. Süßwasserflora von Mitteluropa Bacillariophyceae, Band, $2 / 3$ 3,.Teil: Centrales, Fragillariaceae, Eunotiaceae. K. Krammer and H. Lange Bertalot, 1, Gustav Fischer Verlag, Stuttgart (1991).
11. Süßwasserflora von Mitteluropa Bacillariophyceae, Band, 2/4 4, Teil:Acnanthaceae, Kritische Erganzungen zu Navicula (Lineolatae) und Gomphonema Gesamtliteraturverzeichnis. K. Krammer and H. Lange Bertalot, 2, Gustav Fischer Verlag, Stuttgart (1999).

12. Süßwasserflora von Mitteluropa Bacillariophyceae, Band 2/1, 1.Teil:Naviculaceae. K. Krammer and H. Lange Bertalot, 1, Spectrum Academischer Verlag, Heidelberg, Berlin (1999).

13. Süßwasserflora von Mitteluropa Bacillariophyceae, Band 2/2, 2.Teil: Bacillariaceae, Epithemiaceae, Surirellaceae. K. Krammer and H. Lange Bertalot, 2, Spectrum Academischer Verlag, Heidelberg, Berlin (1999).

14. H.J.H. Mackereth, J. Heron and J.F. Talling, Water Analysis and Some Revised Methods for Limnologists, Sci. Pub. Freshwater Biol., Ambleside, UK, p. 36 (1978).

15. J.F. Talling and D. Driver, In Proceedings of Conference on Primary Production Measurement: Marine and Freshwater Some Problems in the Estimation of Chlorophyll a in Phytoplankton, USA, pp. 76307633 (1961).

16. I.C. Onyema and D.I. Nwankwo, Academia Arena, 1, 30 (2009).

17. D.L. Correll, J. Environ. Qual., 27, 266 (1998).

18. R.G. Wetzel, Limnology, Saunders College Publis., Philadelphia, p. 238 (1983).

19. Eutrophication of Waters, Monitoring, Assessment and Control, OECD (1982).

20. C. Ye, Z. Shen, T. Zhang, M. Fan and Y.J. Lei, J. Environ. Sci., 23, 227 (2011). 